\title{
Activation of NAG-1 via JNK signaling revealed an isochaihulactone-triggered cell death in human LNCaP prostate cancer cells
}

Sheng-Chun Chiu ${ }^{1,2}$, Mei-Jen Wang ${ }^{1,2}$, Hsueh-Hui Yang ${ }^{2}$, Shee-Ping Chen ${ }^{3}$, Sung-Ying Huang ${ }^{4}$, Yi-Lin Chen ${ }^{5}$, Shinn-Zong Lin ${ }^{6}$, Horng-Jyh Harn ${ }^{7 *+}$ and Cheng-Yoong Pang ${ }^{1,2^{*+}}$

\begin{abstract}
Background: We explored the mechanisms of cell death induced by isochaihulactone treatment in LNCaP cells.

Methods: LNCaP cells were treated with isochaihulactone and growth inhibition was assessed. Cell cycle profiles after isochaihulactone treatment were determined by flow cytometry. Expression levels of cell cycle regulatory proteins, caspase 9, caspase 3, and PARP were determined after isochaihulactone treatment. Signaling pathway was verified by inhibitors pre-treatment. Expression levels of early growth response gene 1 (EGR-1) and nonsteroidal anti-inflammatory drug-activated gene 1 (NAG-1) were determined to investigate their role in LNCaP cell death. NAG-1 expression was knocked down by si-NAG-1 siRNA transfection. Rate of cell death and proliferation were obtained by MTT assay.

Results: Isochaihulactone caused cell cycle arrest at G2/M phase in LNCaP cells, which was correlated with an increase of p53 and p21 levels and downregulation of the checkpoint proteins cdc25c, cyclin B1, and cdc2. Bcl-2 phosphorylation and caspase activation were also observed. Isochaihulactone induced phosphorylation of c-Jun-Nterminal kinase (JNK), and JNK inhibitor partially reduced isochaihulactone-induced cell death. Isochaihulactone also induced the expressions of EGR-1 and NAG-1. Expression of NAG-1 was reduced by JNK inhibitor, and knocking down of NAG-1 inhibited isochaihulactone-induced cell death.
\end{abstract}

Conclusions: Isochaihulactone apparently induces G2/M cell cycle arrest via downregulation of cyclin B1 and cdc2, and induces cellular death by upregulation of NAG-1 via JNK activation in LNCaP cells.

\section{Background}

Prostate cancer is the most common malignancy in American men and the second leading cause of deaths from cancer [1]. In the early stage, prostate cancer usually grows slowly and remains confined to the gland, initially producing few or no symptoms. As the cancer advances, it can, however, spread beyond the prostate into the surrounding tissues and to other areas, such as the bones, lungs, and liver. Therefore, symptoms often appear after the cancer has processed to an advanced stage.

\footnotetext{
* Correspondence: duke_harn@yahoo.com.tw; cypang@mail.tcu.edu.tw † Contributed equally

${ }^{1}$ Institute of Medical Sciences, Tzu-Chi University, Hualien, Taiwan

${ }^{7}$ Pathology Department, China Medical University, Taichung, Taiwan Full list of author information is available at the end of the article
}

The treatment options for patients with prostate cancer include surgery, radiation therapy, hormonal therapy, chemotherapy, cryotherapy, and combinations of some of these treatments. At the early stage, surgery, radiation therapy, and hormonal therapy are the preferred treatments. As the cancer processes, chemotherapy and cryotherapy become the preferred treatments. One of the most common drug classes for chemotherapy treatments for prostate cancer is the taxanes, which include the first-generation drug paclitaxel (Taxol, a trademark of Bristol-Myers Squibb) [2,3]. Because taxanes often cause significant negative side effects, newly developed drugs are valuable.

Recently, non-traditional treatments such as herbs and dietary supplements have been considered as alternative medicines. Nan-Chai-Hu (Chai $\mathrm{Hu}$ of the South), the

\section{Biomed Central}

(c) 2011 Chiu et al; licensee BioMed Central Ltd. This is an Open Access article distributed under the terms of the Creative Commons Attribution License (http://creativecommons.org/licenses/by/2.0), which permits unrestricted use, distribution, and reproduction in any medium, provided the original work is properly cited. 
root of Bupleurum scorzonerifolium, is an important Chinese herb in the treatment of influenza, fever, malaria, cancer, and menstrual disorders in China, Japan, and many other parts of Asia. We previously showed that the crude acetone extract of $B$. scorzonerifolium (BS-AE) causes cell cycle arrest at the G2/M phase and apoptosis in the human lung carcinoma cell line A549 [4-6]. After the acetone extract fraction was further purified, a novel lignan, isochaihulactone, which has antitumor activity against A549 cells in vitro and in vivo, was identified [7]. Isochaihulactone induces G2/M arrest and apoptosis in cancer cells. This compound can also be isolated from Bursera microphylla (Burseraceae) and shows antitumor effects [8].

Here we describe the anti-tumor activity of isochaihulactone, which causes cell cycle arrest at G2/M phase and cell death in LNCaP cells. We provided evidence that the disruption of the cell cycle at G2/M phase and the activation of phospho-Bcl-2 and caspase-3 are important in isochaihulactone-induced cell death. Recently, we found isochaihulactone induces growth inhibition and apoptosis in A549 cells by activating early growth response gene 1 (EGR-1) and nonsteroidal anti-inflammatory drug-activated gene 1 (NAG-1) through an extracellular signal-regulated kinase 1/2 (ERK 1/2)-dependent pathway, but PI3K signaling is not involved [9]. Here we show that isochaihulactone induced growth inhibition and cell death in prostate cancer cells by activating EGR-1 and NAG1 through JNK-dependent pathway and that did not involve activation of ERK signaling. Also, isochaihulactone-induced cell death can be restored by siNAG-1 siRNA transfection. Our findings indicate that isochaihulactone is a potential antitumor compound for prostate cancer therapy.

\section{Methods}

\section{Cells and cell culture}

LNCaP human prostate cells, obtained from ATCC (American Type Culture Collection, Manassas, VA), were cultured in RPMI 1640 medium with $10 \%$ heatinactivated fetal bovine serum, $100 \mathrm{U} / \mathrm{ml}$ penicillin and $100 \mathrm{U} / \mathrm{ml}$ streptomycin, $1 \%$ sodium pyruvate, $2 \mathrm{mM} \mathrm{L-}$ glutamine (all of these reagents are from Invitrogen, Carlsbad, CA) at $37^{\circ} \mathrm{C}$ in a humidified atmosphere with $5 \% \mathrm{CO}_{2}$. Cells were plated in 6-well plates at a seeding density of approximately $2 \times 10^{5}$ cells/well in the presence or absence of isochaihulactone $(20 \mu \mathrm{M})$.

\section{Chemicals and reagents}

Bupleurum scorzonerifolium roots were supplied by Chung-Yuan Co. (Taipei, Taiwan). The plant was identified and deposited at National Defense Medicinal Center (NDMCP No. 900801). Isochaihulactone (4-benzo[1,3] dioxol-5-ylmethyl-3-(3,4,5-trimethoxyl-benzylidene)dihydro-furan-2-one) was prepared as described previously [7]. RPMI 1640 medium, fetal bovine serum (FBS), penicillin, streptomycin, L-glutamine, sodium pyruvate, trypsin/EDTA were purchased from Invitrogen. The RNA isolation kit was purchased from QIAGEN (Valencia, CA). Dimethyl sulfoxide (DMSO), 3-(4,5dimethyl thizol-2-yl)-2,5-diphenyl tetrazolium bromide (MTT), paclitaxel, and horseradish peroxidase-conjugated secondary antibodies were purchased from Sigma Chemical Co. (St. Louis, MO, USA). The ERK1/2 kinase inhibitor PD98059 and the JNK inhibitor SP600125 were purchased from R\&D Systems (Minneapolis, MN). The p38 inhibitor SB203580 and the PI3K/AKT inhibitor LY294002 were purchased from Calbiochem (San Diego, CA). The annexin-V-FLUOS Staining Kit was from Roche Molecular Biochemicals (Mannheim, Germany). Polyvinyldenefluoride (PVDF) membranes, BSA protein assay kit and western blot chemiluminescence reagent were purchased from Amersham Biosciences (Arlington Heights, IL).

\section{Western blot analysis}

LNCaP cells were lysed on ice with $200 \mu \mathrm{l}$ of lysis buffer (50 mM Tris- $\mathrm{HCl}$, pH 7.5, $0.5 \mathrm{M} \mathrm{NaCl}, 5 \mathrm{mM} \mathrm{MgCl}$, $0.5 \%$ Nonidet P-40, $1 \mathrm{mM}$ phenylmethylsulfonyl fluoridefor, $1 \mu \mathrm{g} / \mathrm{ml}$ pepstatin, and $50 \mu \mathrm{g} / \mathrm{ml}$ leupeptin) and centrifuged at $13,000 \times \mathrm{g}$ at $4^{\circ} \mathrm{C}$ for $5 \mathrm{~min}$. The protein concentrations in the supernatants were quantified using a BSA Protein Assay Kit. Electrophoresis was performed on a NuPAGE Bis-Tris Electrophoresis System using $30 \mu \mathrm{g}$ of reduced protein extract per lane. Resolved proteins were then transferred to PVDF membranes. Membranes were blocked with 5\% non-fat milk for $1 \mathrm{~h}$ at room temperature and probed with appropriately dilution of primary antibodies at $4{ }^{\circ} \mathrm{C}$ overnight: NAG-1/PTGF-b (1:1000, Upstate Biotechnology, Lake Placid, NY), phospho-ERK1/2 (1:2000), ERK1/2 (1:2000), phospho-p38 (1:1000), p38 (1:1000), phospho-JNK1/2 (1:1000), JNK1/2 (1:1000), cyclin B1 (1:1000), cdc2 (1:1000), cleaved Caspase-3 (Asp175) (1:1000), cleaved Caspase-8 (1:1000), cleaved Caspase-9 (Asp330) (1:1000), PARP (46D11) (1:1000), phospho-Bcl-2 (ser70) (1:1000), p53 (1:1000), were purchased from Cell Signaling Technology, Inc. (Danvers, MA). After the PVDF membrane was washed three times with TBS/0.2\% Tween 20 at room temperature, it was incubated with appropriate secondary antibody (goat anti-mouse or anti-rabbit, 1:10000, Sigma Chemical, St. Louis, MO) labeled with horseradish peroxidase for $1 \mathrm{~h}$ at room temperature. All proteins were detected using Western Lightning ${ }^{\mathrm{TM}}$ Chemiluminescence Reagent Plus (Amersham Biosciences, Arlington Heights, IL) and quantified with densitometers. 


\section{Growth inhibition assay}

The viability of the cells after treatment with various chemicals was evaluated using MTT assay preformed in triplicate. Briefly, the LNCaP cells $\left(2 \times 10^{5} /\right.$ well $)$ were incubated in 6-well plates containing $2 \mathrm{ml}$ of serum-containing medium. Cells were allowed to adhere for 18-24 $\mathrm{h}$ and then were washed with phosphate-buffered saline (PBS). Solutions were always prepared fresh by dissolving $0.2 \%$ DMSO (control) or drugs in culture medium before their addition to LNCaP cells. For inhibitor treatment experiments, cells were pre-incubated for $1 \mathrm{~h}$ with $25 \mu \mathrm{M}$ and $50 \mu \mathrm{M}$ ERK1/2 kinase inhibitor PD98059, $10 \mu \mathrm{M}$ and $20 \mu \mathrm{M}$ p38k inhibitor SB203580, or $10 \mu \mathrm{M}$ and $20 \mu \mathrm{M}$ JNK inhibitor SP600125 and then were treated with $20 \mu \mathrm{M}$ isochaihulactone for $24 \mathrm{~h}$. The drug-containing medium was removed, cells were washed with PBS, and culture medium containing $300 \mu \mathrm{g} / \mathrm{ml}$ MTT was added for $1 \mathrm{~h}$ at $37^{\circ} \mathrm{C}$. After the medium were removed, $2 \mathrm{ml}$ of DMSO were added to each well. Absorbance at 570 $\mathrm{nm}$ of the maximum was detected by a PowerWave $x$ Microplate ELISA Reader (Bio-Tek Instruments, Winooski, VT). The absorbance for DMSO-treated cells was considered as $100 \%$. The results were determined by three independent experiments.

\section{Cell cycle analysis}

The cell cycle was determined by flow cytometry following DNA staining to reveal the total amount of DNA. Approximately $5 \times 10^{5}$ of LNCaP cells were incubated with $20 \mu \mathrm{M}$ isochaihulactone for the indicated time. Cells were harvested with trypsin/EDTA, collected, washed with PBS, fixed with cold $100 \%$ ethanol overnight, and then stained with a solution containing $45 \mathrm{mg} / \mathrm{ml} \mathrm{PI}, 10 \mathrm{mg} / \mathrm{ml} \mathrm{RNase} \mathrm{A}$, and $0.1 \%$ Triton X-100 for $1 \mathrm{~h}$ in the dark. The cells were then passed through FACScan flow cytometer (equipped with a 488-nm argon laser) to measure the DNA content. The data were obtained and analyzed with CellQuest 3.0.1 (Becton Dickinson, Franklin Lakes, NJ) and ModFitLT V2.0 software.

\section{Transfection with siRNA}

NAG-1 siRNA was designed by siGENOME SMARTpool duplex siRNA and purchased from Dharmacon RNAi Technologies (Chicago, IL). LNCaP cells at 50 to $60 \%$ confluence were transfected with NAG-1 siRNA (10-50 $\mathrm{nM}$ ) for $48 \mathrm{~h}$ using RNAifect Transfection Reagent (QIAGEN). The medium was removed, and the cells were treated with isochaihulactone or vehicle for up to $48 \mathrm{~h}$. Proteins were then isolated for western blotting, or cells were collected for the MTT assay.

\section{Immunocytochemistry}

LNCaP cells cultured on glass slides were treated with $20 \mu \mathrm{M}$ isochaihulactone for $48 \mathrm{~h}$ prior to fixation with cold $4 \%$ paraformaldehyde. The fixed cells were washed twice in PBS, and incubated in cold permeabilization solution $(0.3 \%$ Triton X-100 + 0.1\% sodium citrate) . After endogenous peroxidase activity was inactivated with $3 \% \mathrm{H}_{2} \mathrm{O}_{2}$, the cells were washed with PBS and incubated with an anti-cleaved caspase- 3 at $4{ }^{\circ} \mathrm{C}$ overnight. The cells were washed with PBS three times and then incubated with FITC-conjugated secondary antibody $1 \mathrm{~h}$ at room temperature. The cells were then washed with PBS three times and stained with $300 \mathrm{nM}$ DAPI for $10 \mathrm{~min}$. Images were obtained with a confocal microscope (Carl Zeiss, Oberkochen, Germany).

\section{TUNEL assay}

LNCaP cells were cultured in the presence or absence of isochaihulactone $(20 \mu \mathrm{M})$ for $60 \mathrm{~h}$ and then examined for apoptosis with TUNEL assay (In Situ Cell Death Detection Kit, Roche).

\section{Statistical analysis}

The data are shown as mean \pm S.D. Statistical differences were analyzed using the Student's $t$-test for normally distributed values and by nonparametric MannWhitney $U$-test for values with a non-normal distribution. Values of $P<0.05$ were considered significant.

\section{Results}

Isochaihulactone inhibited proliferation and induced morphology changes of the human prostate cancer cells

Isochaihulactone has a strong anti-proliferative effect on A549 cells and caused G2/M phase arrest and apoptosis in a time- and concentration-dependent manner [7]. To determine the cytotoxicity of isochaihulactone on prostate cancer cells, three human prostate cancer cell lines, namely, DU-145, PC3, and LNCaP were tested. The MTT assay revealed that isochaihulactone had a strong anti-proliferative effect on human prostate cancer cell lines, especially the LNCaP cells (Figure 1A). LNCaP cells were selected for subsequent studies. Compared with untreated cells, isochaihulactone-treated LNCaP cells showed obvious cell shrinkage and rounding up, features typical of cells undergoing apoptosis (Figure 1B and $1 \mathrm{C})$. The MTT assay showed that isochaihulactone had anti-proliferative effects on LNCaP cells that were time- and dose-dependent (Figure 1D). Treatment of LNCaP cells with $25 \mu \mathrm{M}$ isochaihulactone for $48 \mathrm{~h}$ resulted in $48.3 \%$ cell survival, whereas treatment for 72 $\mathrm{h}$ resulted in $32 \%$ cell survival (Figure 1D). Based on these data, we used $20 \mu \mathrm{M}$ isochaihulactone for 
A

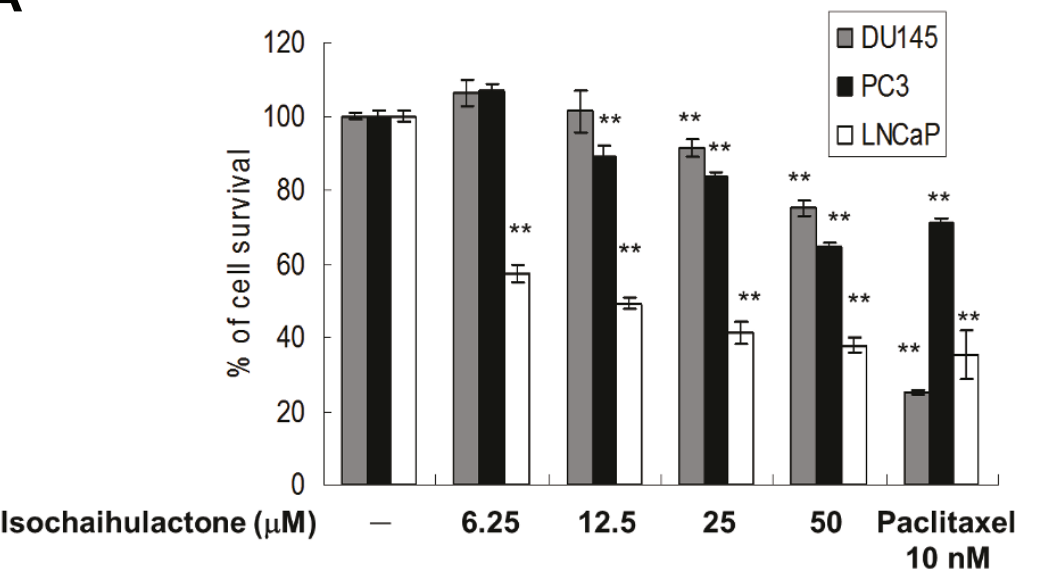

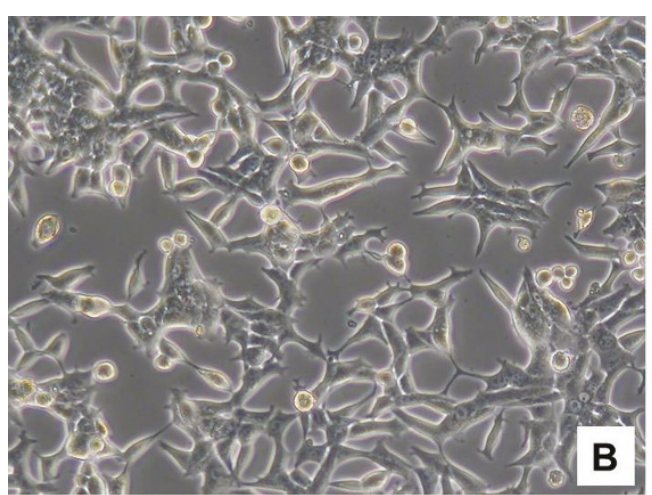

Control, $24 \mathrm{~h}, \mathbf{1 0 0 X}$

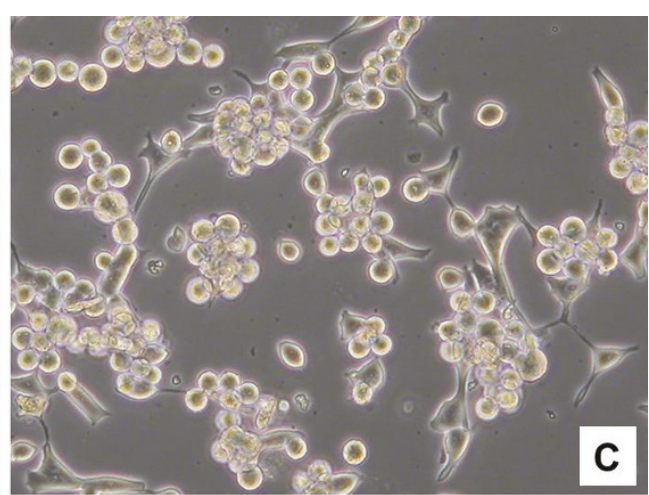

Isochaihulactone $(20 \mu \mathrm{M}), 24 \mathrm{~h}, 100 \mathrm{X}$

D

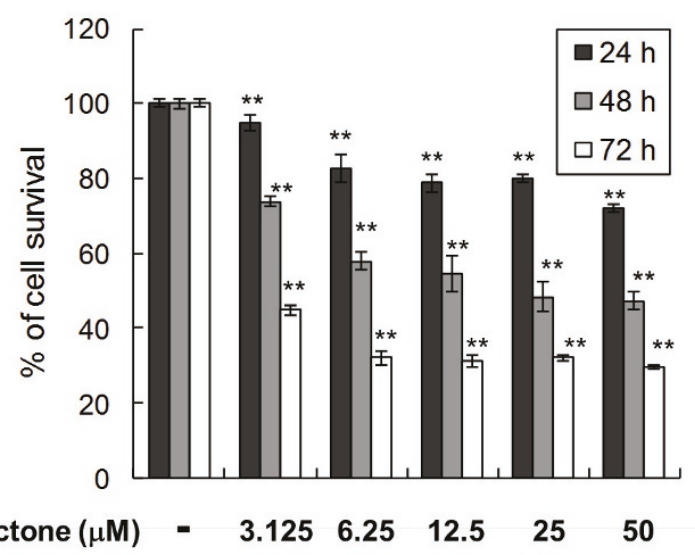

Figure 1 Morphological changes and anti-proliferation effects after isochaihulactone treatment of prostate cancer cells. (A) Human prostate cancer cell lines DU-145, PC-3, LNCaP were treated with isochaihulactone from 6.25 to $50 \mu \mathrm{M}$ at $48 \mathrm{~h}$ and analyzed with the MTT assay. LNCaP cells were treated with $0.2 \%$ DMSO as a control (B) or $20 \mu \mathrm{M}$ isochaihulactone (C) for $24 \mathrm{~h}$. LNCaP cells were treated with increasing concentration of isochaihulactone from 3.125 to $50 \mu \mathrm{M}$ at various times from 24 to $72 \mathrm{~h}$ and analyzed with the MTT assay (D). The data represent the means \pm S.D. from three independent experiments. ${ }^{*}, P<0.01$ versus vehicle. 
subsequent studies $(50.5 \%$ cell survival after $48 \mathrm{hr}$ treatment and data not shown).

\section{Isochaihulactone induced cell cycle arrest in G2/M phase and changed the expression levels of G2/M regulatory proteins}

In order to elucidate its mode of action, we examined effects of isochaihulactone on cell cycle progression. Flow cytometry analysis showed that isochaihulactone treatment resulted in the accumulation of cells in $\mathrm{G} 2 / \mathrm{M}$ phase in a time-dependent manner (Figure 2A). Quantification of proliferating untreated LNCaP cells showed that $67.3 \%$ of cells were in the G0/G1 phase, $22.8 \%$ of cells were in the $\mathrm{S}$ phase, and $9.7 \%$ of cells were in the $\mathrm{G} 2 / \mathrm{M}$ phase of cell cycle $48 \mathrm{~h}$ after plating. Treatment of LNCaP cells with $20 \mu \mathrm{M}$ isochaihulactone for $48 \mathrm{~h}$ increased the percentage of cells in the $\mathrm{G} 2 / \mathrm{M}$ phase to

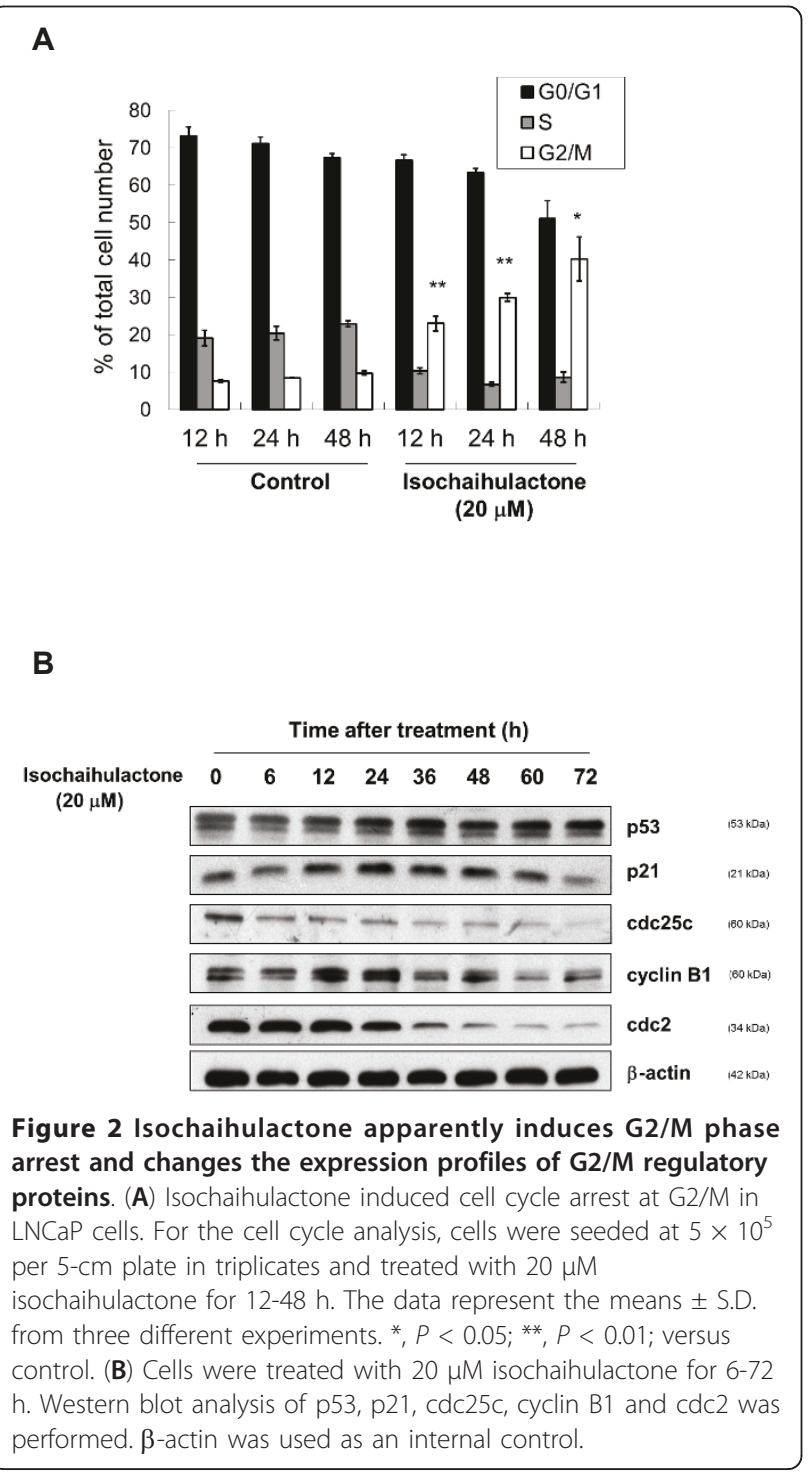

$40.2 \%$ and reduced the percentage of the cells in the G0/G1 and S phase (51.1 and 8.6\%, respectively). The subdiploid population of cells accounted for $\sim 2 \%$.

To determine the relationship between isochaihulactone-induced mitotic arrest and p53, p21, cdc25c, and cyclinB1/cdc2 activities and Bcl-2 phosphorylation, we first examined the expression of these G2/M regulatory proteins in LNCaP cells treated with $20 \mu \mathrm{M}$ isochaihulactone for increasing times. Western blot analysis showed that treatment of LNCaP cells with isochaihulactone resulted in upregulation of p53 and p21 and downregulation of cdc25c, cyclin B1, and cdc2 in a time-dependent manner (Figure $2 \mathrm{~B}$ ). These data suggest that isochaihulactone apparently induced LNCaP cells to undergo $\mathrm{G} 2 / \mathrm{M}$ growth arrest by affecting the expression of $\mathrm{G} 2 / \mathrm{M}$ regulatory proteins.

\section{Isochaihulactone induced LNCaP cell death}

To evaluate the role of apoptosis in isochaihulactoneinduced cell death, caspase-3 staining and TUNEL staining were performed. After treatment with $20 \mu \mathrm{M}$ isochaihulactone for $48 \mathrm{~h}$, the LNCaP cells were fixed and stained with anti-caspase 3 , an increased number of FITC-positive cells were seen (Figure 3B) as compared to control cells (Figure 3A). To observe the late stage of apoptosis, LNCaP cells treated with $20 \mu \mathrm{M}$ isochaihulactone for $60 \mathrm{~h}$ was collected and stained with TUNEL staining kit. Most of the isochaihulactone-treated cells were TUNEL positive (Figure 3D) as compared with untreated cells (Figure 3C). Because activation of the caspases and cleavage of PARP are crucial mechanisms for induction of apoptosis, their involvement in isochaihulactone-induced cell death was investigated in LNCaP cells. In addition, Bcl-2, which is located on the outer mitochondrial membrane, is important for the suppression of mitochondrial manifestations of apoptosis [10]. We examined whether isochaihulactone-induced cell death was associated with Bcl-2 phosphorylation. Caspase- 9 and caspase- 3 , but not caspase- 8 , were activated after isochaihulactone treatment (Figure 3E). Thus, isochaihulactone-induced cell death is mediated through a caspase-dependent pathway. We also observed that caspase-9 activation, Bcl-2 phosphorylation, and cleavage of caspase- 3 and PARP in a time-dependent manner (Figure $3 \mathrm{E})$.

\section{Isochaihulactone-induced JNK1/2 activation was followed by growth inhibition of LNCaP cells}

In our previous study, the anti-proliferative activity of isochaihulactone in A549 cells was via ERK1/2, mitogen-activated protein kinase (MAPK) pathway. To examine whether this pathway is activated in isochaihulactone-treated LNCaP cells, cells were treated with isochaihulactone for $48 \mathrm{~h}$ in the presence and absence of 

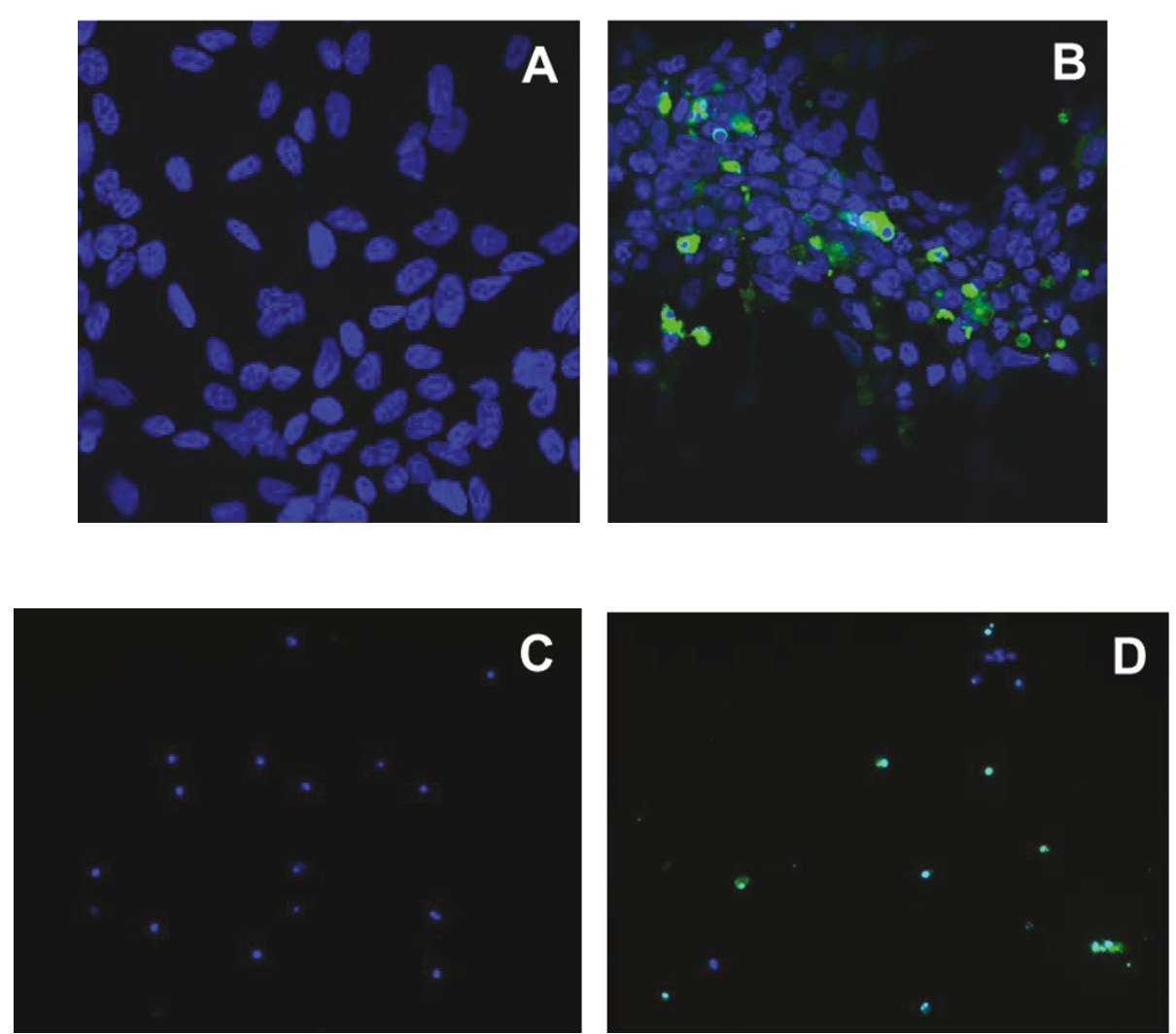

E Time after treatment $(\mathrm{h})$

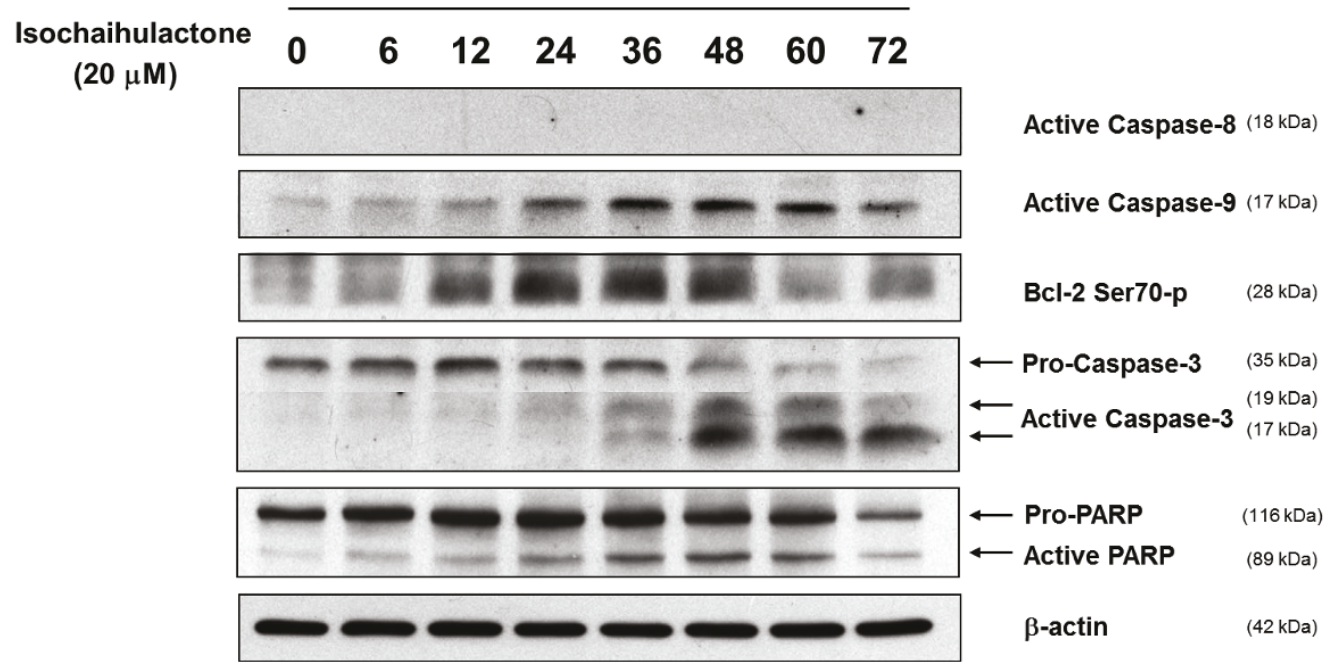

Figure 3 Isochaihulactone induces cell death and initiates Bcl-2 phosphorylation and caspase activation in LNCaP cells. LNCaP cells were treated with $0.2 \%$ DMSO (A) or $20 \mu \mathrm{M}$ isochaihulactone (B) for $48 \mathrm{~h}$ and then were fixed and stained for cleaved caspase-3. Nuclei were stained with DAPI. LNCaP cells were treated with $0.2 \%$ DMSO $(\mathbf{C})$ or $20 \mu \mathrm{M}$ isochaihulactone (D) for $60 \mathrm{~h}$ and then were fixed and stained with the TUNEL assay. Nuclei were stained with DAPI. (E) Isochaihulactone induced caspase-9 activation, followed by Bcl-2 phosphorylation and then caspase-3 activation. Cells were treated with $20 \mu \mathrm{M}$ isochaihulactone for the indicated time and analysis by Western blotting. Membranes were probed with caspase-8, phosphor-Asp330 caspase-9, phosphor-Ser70 Bcl-2, cleaved- $\beta$ aspase-3, PARP antibodies. $\beta$-actin was used as an internal control. 
the MEK1/2 inhibitor PD98059 (25 or $50 \mu \mathrm{M})$, the p38 inhibitor SB203580 (10 or $20 \mu \mathrm{M})$, or the JNK1/2 inhibitor SP600125 $(10$ or $20 \mu \mathrm{M})$. Only SP600125 significantly blocked isochaihulactone-induced growth inhibition in a concentration-dependent manner (Figure 4A). We also found that isochaihulactone had no effect on the activation of ERK1/2 (Figure 4B) or PKC (data not shown). Furthermore, to determine which JNK pathways were involved, we evaluated the effect of isochaihulactone on ERK1/2, p38, and JNK1/2 activation. We found that only JNK1/2 showed increased phosphorylation after exposure of LNCaP cells to isochaihulactone for 10-120 min (Figure 4B). In contrast, isochaihulactone had no effect on the phosphorylation of p38 or ERK1/2. To further clarify the role of JNK signaling pathway in isochaihulactone-induced LNCaP cell death, cell cycle analysis was performed in the presence or absence of JNK inhibitor SP600125 by flow cytometry. As shown in Figure 4C, the JNK inhibitor SP600125 (20 $\mu \mathrm{M})$ significantly reduced the sub-G1 population induced by isochaihulactone from $20.51 \%$ to $7.54 \%$. These data suggested that JNK signaling pathway was involved in the mechanism of isochaihulactone-induced cell death.

\section{Isochaihulactone induced EGR-1 and NAG-1 expression in LNCaP cells}

Recently, isochaihulactone was shown to upregulate NAG-1 expression in the human lung carcinoma cell line A549 through an ERK-dependent pathway involving the activation of EGR-1 [9]. To evaluate whether EGR-1 and NAG-1 were involved in the anti-proliferative effect of isochaihulactone in $\mathrm{LNCaP}$ cells, the expression of EGR-1 and NAG-1 proteins was determined by western blot analysis. After exposure of cells to isochaihulactone, the expressions of both EGR-1 and NAG-1 were upregulated in a time-dependent manner. EGR-1 was significantly induced at $6 \mathrm{~h}$ after isochaihulactone treatment, and this effect was maintained until 36 h. NAG-1 expression occurred later, with the highest expression at 60-72 h (Figure 5A).

\section{The JNK $1 / 2$ signaling pathway was involved in isochaihulactone-induced NAG-1 expression}

To investigate a possible role for JNK $1 / 2$ in the regulation of NAG-1 expression, LNCaP cells were treated with isochaihulactone $(20 \mu \mathrm{M})$ in the presence and absence of the p38 inhibitor SB203580 $(20 \mu \mathrm{M})$, the JNK1/2 inhibitor SP600125 $(20 \mu \mathrm{M})$, or the MEK1/2 inhibitor PD98059 $(50 \mu \mathrm{M})$. Using western blot analysis, we found that inhibition of JNK1/2 expression with SP600125 reduced NAG-1 protein levels after treatment of LNCaP cells with isochaihulactone (Figure 5B). In contrast, inhibition of ERK1/2 or p38 had no effect on the induction of NAG-1 (Figure 5B). These results suggest that activation of the JNK1/2 signaling pathway was involved in isochaihulactone-induced NAG-1 expression.

\section{Induction of NAG-1 was involved in isochaihulactone- induced LNCaP cell death}

Since the expressions of EGR-1 and NAG-1 were observed in isochaihulactone-induced A549 apoptotic cell death, their roles in LNCaP cell death were investigated. To determine the role of NAG-1 in the anticancer potential of isochaihulactone in prostate cancer, we used an siRNA approach. Western blot analysis confirmed the suppression of NAG-1 by NAG-1 siRNA in a concentration-dependent manner (Figure 5C). To further characterize the role of NAG-1 in isochaihulactone-induced growth inhibition, LNCaP cells were transfected with siNAG-1 siRNA for $48 \mathrm{~h}$. Then, the MTT assay was performed to determine the percentage of cell death $48 \mathrm{~h}$ after treatment with $20 \mu \mathrm{M}$ isochaihulactone. Nineteen and $24 \%$ of cell death was inhibited by 20 and 40 nM NAG-1 siRNA, respectively, after exposure of cells to $20 \mu \mathrm{M}$ isochaihulactone (Figure 5D). Thus, isochaihulactone-induced cell death in LNCaP cells occurred partially through NAG-1 activation.

\section{Discussion}

In our previous study, we demonstrated that isochaihulactone was efficacious against various models of human solid tumors but not prostate cancer [7]. We also have shown recently that isochaihulactone triggers an apoptotic pathway in human A549 lung cancer cells that occurs via the ERK1/2 and NAG-1 pathway [9]. To clarify the mechanisms of isochaihulactone-induced tumor apoptosis between different types of cancer cells, we further investigated the antitumor potential and mechanisms of isochaihulactone action in human prostate cancer cells. Three human prostate cell lines were used to test the cytotoxicity of isochaihulactone, only the LNCaP prostate cancer cells showed sensitivity to isochaihulactone treatment. This phenomenon might be important to the antitumor potential of isochaihulactone and is discussed later.

In this study, we demonstrated that isochaihulactone apparently induced G2/M cell cycle arrest and cell death in LNCaP cells. The tumor suppressor protein p53 plays a role in the molecular response to DNA damage and cell cycle arrest. The cyclin-dependent kinase inhibitor p21 also helps to maintain G2/M cell cycle arrest by inactivating the cyclin $\mathrm{B} 1 / \mathrm{cdc} 2$ complex, disrupting the interaction between proliferating cell nuclear antigen and cdc25c [11]. Our result showed that increased levels of p53 and p21 proteins were expressed in LNCaP cells in response to treatment with isochaihulactone (Figure 2B). The transition from G2 phase to mitosis is 
A

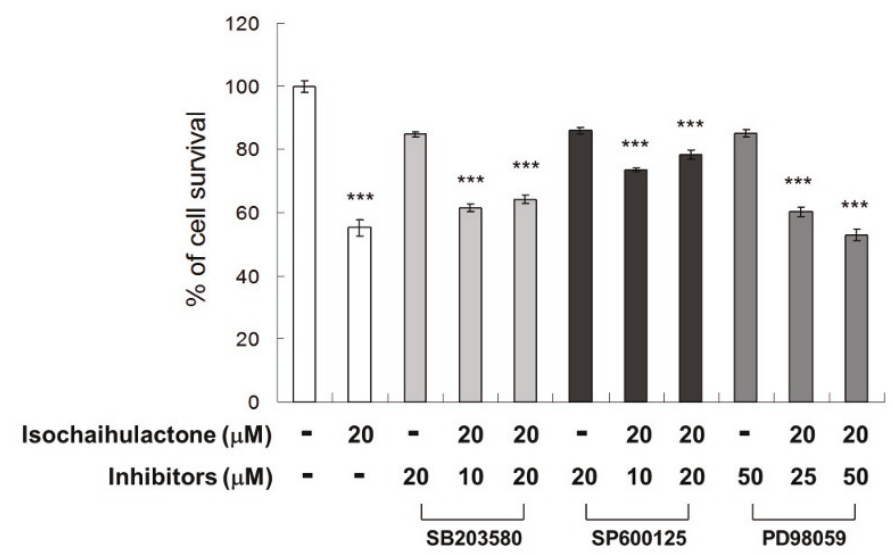

B
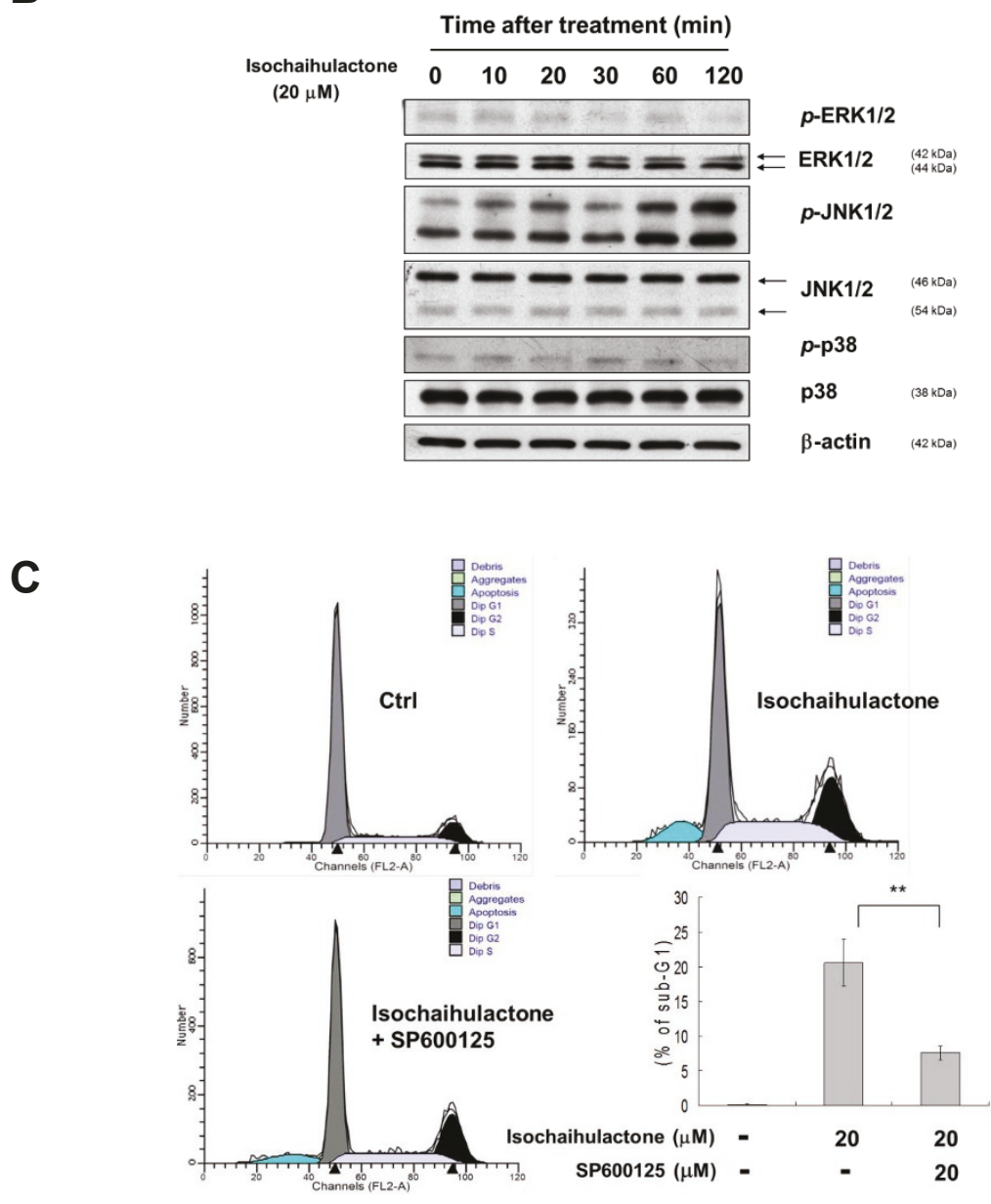

Figure 4 Growth inhibition of LNCaP cells induced by isochaihulactone is partially rescued by JNK1/2 inhibitor. (A) MTT assay of LNCaP cells pretreated with p38 inhibitor SB203580 (10 or $20 \mu \mathrm{M})$, the JNK1/2 inhibitor SP600125 (10 or $20 \mu \mathrm{M})$ or the ERK1/2 inhibitor PD98059 (25 or $50 \mu \mathrm{M})$ for $1 \mathrm{~h}$ and then treated with $20 \mu \mathrm{M}$ of isochaihulactone for $48 \mathrm{~h}$. The values are the mean \pm S.D. from three independent experiments performed in duplicate. (B) Cells were treated with $20 \mu \mathrm{M}$ isochaihulactone for the indicated times. Phospho-ERK1/2, total-ERK1/2, phospho-JNK, total-JNK, phospho-38, total-p38 were detected by western blotting. (C) Cells were treated with $20 \mu \mathrm{M}$ isochaihulactone for $48 \mathrm{~h}$ in the presence or absence of JNK1/2 inhibitor SP600125 (20 MM). Cell cycle analysis was done as described in Methods. Isochaihulactone-induced sub-G1 population (20.51\%) was decreased by JNK1/2 inhibitor SP600125 pre-treatment (7.54\%). The data represent the means \pm S.D. from three independent experiments. ${ }^{* *}, \mathrm{P}<0.01 ;{ }^{* * *}, P<0.001$ versus vehicle. 


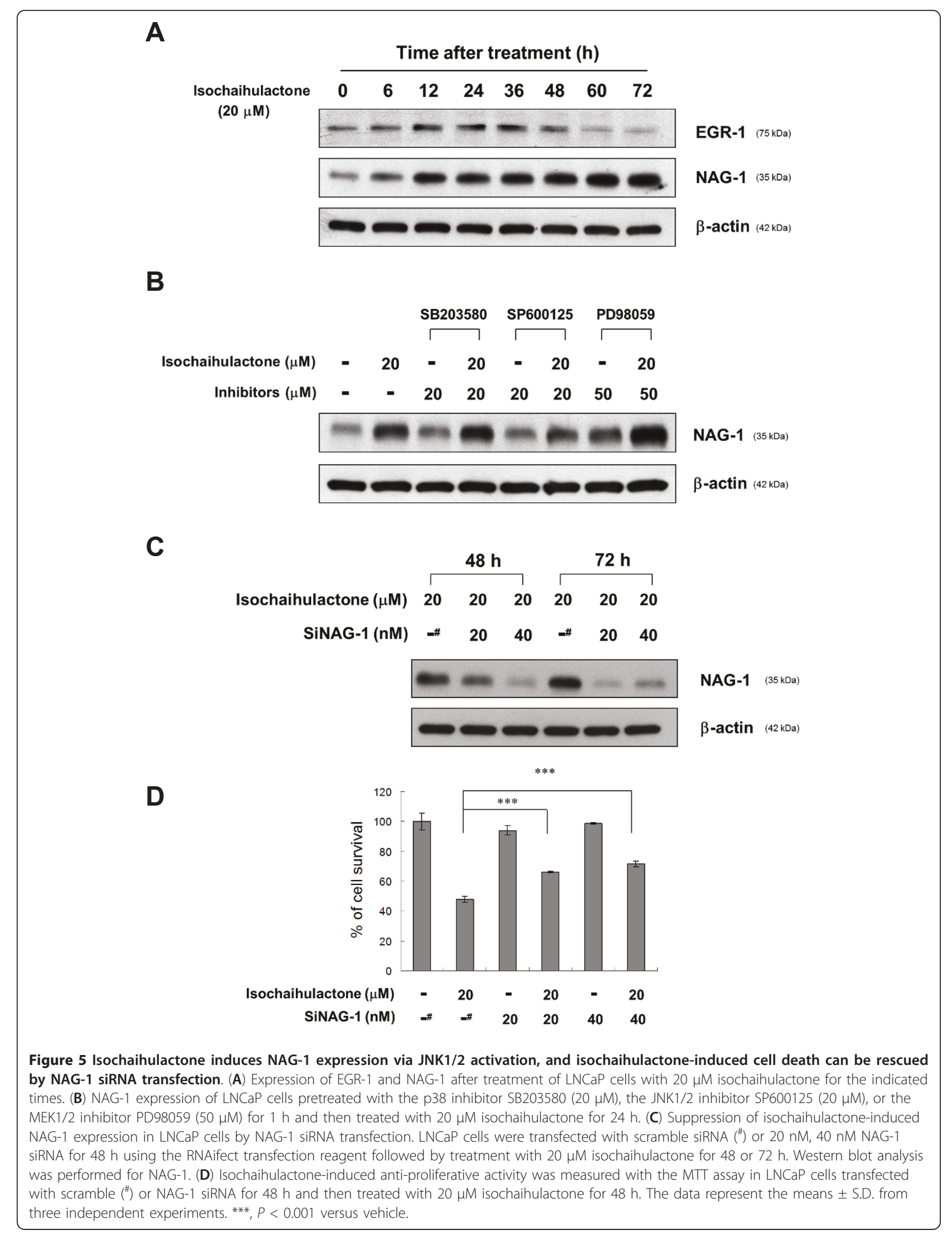


triggered by the cdc25c-mediated activation of the cyclin $\mathrm{B} 1 / \mathrm{cdc} 2$ complex. Cyclin B1/cdc2 activation is triggered when cdc25c dephosphorylates Thr15 [12,13]. In our study, isochaihulactone-mediated LNCaP cell cycle arrest at G2/M phase (Figure 2B) was accompanied by decreased expression of cyclin B1 and cdc2 kinase. The decrease in the levels of cdc2 may be due to the decrease in cdc 25 activation by phosphorylation, leading to subsequent G2 arrest (Figure 2B).

Activation of aspartate-specific cysteine protease (caspase) represents a crucial step in the induction of druginduced apoptosis, and cleavage of PARP by caspase- 3 is considered to be one of the hallmarks of apoptosis [14]. Isochaihulactone-induced caspase 3 cleavage was observed by immunocytochemistry (Figure 3B), and late-stage apoptosis was revealed by TUNEL staining (Figure 3D). Furthermore, isochaihulactone inhibited Bcl-2 expression, induced caspase- 9 and caspase- 3 cleavage, and induced PARP activation were also observed (Figure 3E). It is interesting to note that isochaihulactone-induced $\mathrm{Bcl}-2$ phosphorylation, caspase- 9 cleavage, and PARP cleavage were observed at nearly the same time point, suggesting that the isochaihulactone-induced $\mathrm{Bcl}-2$ phosphorylation is related apoptosis (Figure 3E). Recent reports have revealed the involvement of JNKmediated Bcl-2 phosphorylation and degradation, and also the activation of caspase- 9 in the apoptosis of both the androgen-dependent and -independent human prostate cancer cells [15]. Bcl-2 and Bcl-XL inhibit apoptosis by regulating the mitochondrial membrane potential, whereas cytochrome $c$ release is required for activation of caspase- 9 and subsequent activation of caspase- 3 [16]. Thus, increased levels of Bcl-2 phosphorylation, caspase- 9 and -3 activation appeared to correlate with mitochondrial apoptosis in isochaihulactone-induced LNCaP cell death.

Many microtubule-destabilizing agents are activators of caspase-9, a major key player in mitochondrial apoptotic pathway $[17,18]$. Microtubule depolymerization agents arrest the cell cycle in G2/M phase by acting through several types of kinases, which lead to phosphorylation cascades, activation of the cyclin B1/cdc2 complex, and the phosphorylation of Bcl-2 [19]. The MAPK inhibitor PD98059 has been shown to partially inhibit isochaihulactone-induced cdc2 phosphorylation, causing G2/M arrest in A549 cells. The activation of NAG-1 expression via ERK1/2 pathway is involved in isochaihulactone-induced G2/M arrest in A549 cells $[7,9]$. To determine which MAPK family member is involved in the major signaling pathway for isochaihulactone-mediated cell growth inhibition, MAPK inhibitors were used to study the growth inhibition induced by isochaihulactone in LNCaP cells. Only JNK1/2 inhibitor SP600125 significantly decreased the growth inhibition induced by isochaihulactone (Figure 4A), and neither the p38 inhibitor SB203580 nor the ERK1/2 inhibitor PD98059 reversed isochaihulactone-induced growth inhibition. Phosphorylation of JNK kinase was also observed with western blot analysis after isochaihulactone treatment (Figure 4B). In cell cycle analysis, pretreatment of JNK1/2 inhibitor SP600125 significantly reduces sub-G1 population (Figure $4 \mathrm{C}$ ). These data suggest that JNK1/2 signaling pathway is involved in isochaihulactone-induce cell death.

Increased NAG-1 expression results in the induction of apoptosis in several cancer cell lines [20,21]. NAG-1 is induced not only by NSAIDs but also by several antitumorigenic compounds including dietary compounds, peroxisome proliferator-activated receptor- $\gamma$ ligands, phytochemicals [16-18], as well as resveratrol, genistein, diallyldisulfide, 5F203, and retinoid 6-[3-(1-adamantyl)4-hydroxyphenyl]-2-naphthalene carboxylic acid (AHPN) [22-24]. NAG-1 appears to be a key downstream target of EGR-1[9].

In our previously studies, we confirmed the antitumor effect of isochaihulactone [7], and the inhibition of tumor growth that was attributable to NAG-1 protein expression in a nude mice xenograft model [9]. Thus, NAG-1 is an essential factor in the antitumor activity of isochaihulactone. Our current results show that isochaihulactone induced EGR-1 and NAG-1 protein expression in LNCaP cells in a time-dependent manner (Figure 5A). Furthermore, only the JNK1/2 inhibitor SP600125 reduced isochaihulactone-induced NAG-1 protein expression (Figure $5 \mathrm{~B}$ ). These data support that isochaihulactone-induced JNK1/2 activity is critical in regulating NAG-1 expression. In addition, we further confirmed by using siRNA approach that NAG-1 expression has an apoptosis-promoting effect (Figure $5 \mathrm{D})$.

In summary, we found that isochaihulactone increased NAG-1 expression, suggesting that the antitumor effect of isochaihulactone is mediated via this tumor suppressor protein. NAG-1 mRNA is highly expressed in the human prostate epithelium [25], suggesting its role in prostate homeostasis. Despite this, NAG-1 negatively affects LNCaP cell survival [26], and is overexpressed in many tumors including prostate cancer $[27,28]$. NAG-1 may be like other members of the TGF- $\beta$ superfamily, acting as a tumor suppressor in the early stages but becoming pro-tumorigenic during the later stages of tumor progression. The effects of NAG-1 appear to be ambiguous, and under different conditions, NAG-1 exhibits either tumorigenic or anti-tumorigenic activity [24]. Epidemiological studies have shown that patients who use NSAIDs for 10-15 years have a reduced risk of developing cancer [29]. NSAIDs inhibit cyclooxygenase$1(\mathrm{COX}-1)$ and cyclooxygenase-2 (COX-2). Several 
studies have suggested that the tumorigenic or antitumorigenic activity of NAG-1 may be due to the interaction of NAG-1 and cyclooxygenase [21,30,31].

Recent study has revealed a new pathway that Retinoblastoma (RB; encoded by $R B 1$ ) depletion induced unchecked androgen receptor (AR) activity that underpinned therapeutic bypass and tumor progression [32]. The hypo-phosphorylation form of RB suppresses E2F1mediated transcriptional activation and induces cell cycle arrest. Loss of $R B 1$ was observed in most of the castrate-resistant prostate cancer (CRPC), and $A R$ as a gene under the control of E2F1, which in turn is stringently regulated by RB. Since hypo-phosphorylation of $\mathrm{RB}$ was observed after isochaihulactone treatment in LNCaP cells (data not shown), this might explain why $\mathrm{LNCaP}$ is more sensitive to isochaihulactone than the other two androgen-independent prostate cancer cell lines. However, the exact mechanism of these differences needs to be extensively investigated.

\section{Conclusions}

Our current study provides information on the proapoptotic and anti-tumorigenic activity of isochaihulactone in human $\mathrm{LNCaP}$ prostate cancer cell line. Isochaihulactone downregulated expression of G2/M regulatory proteins including cyclin $\mathrm{B} 1, \mathrm{cdc} 2$, cdc25c, apparently resulting G2/M cell cycle arrest. In addition, isochaihulactone-induced cell death was caspase-dependent and occurred through activations of caspase- 9 and caspase- 3 . The JNK1/2 MAPK signaling pathway and NAG-1 expression were implicated in isochaihulactone-induced cell death. These findings suggest that isochaihulactone has a high therapeutic potential for prostate cancer and should be extensively investigated with in vivo studies.

\section{Acknowledgements}

This work was partly supported by grants from the National Science Council, Taiwan (NSC-93-2320-B-303-004, NSC-94-2320-B-303-005 and NSC-96-2113-M303-001), and Buddhist Tzu-Chi General Hospital, Hualien, Taiwan (TCSP-0102). We thank Dr. Tony Jer Fu Lee (PhD, Dean of College of Life Sciences, Tzu Chi University, Hualien, Taiwan) for reviewing the manuscript.

\section{Author details \\ IInstitute of Medical Sciences, Tzu-Chi University, Hualien, Taiwan. ${ }^{2}$ Department of Medical Research, Buddhist Tzu-Chi General Hospital, Hualien, Taiwan. ${ }^{3}$ Tzu-Chi Stem Cell Centre, Buddhist Tzu-Chi General Hospital, Hualien, Taiwan. ${ }^{4}$ Department of Ophthalmology, Mackay Memorial Hospital, Hsinchu, Taiwan. ${ }^{5}$ Graduate Institute of Biotechnology, National llan University, Ilan, Taiwan. ${ }^{6}$ Center for Neuropsychiatry, China Medical University Hospital, Taichung, Taiwan. ${ }^{7}$ Pathology Department, China Medical University, Taichung, Taiwan.}

\section{Authors' contributions}

SCC carried out the most of the experiments and drafted the manuscript MJW, HHY, YLC, SZL participated in the design and coordination of the study. SPC carried out the statistical analysis. SYH carried out the immunostaining. $\mathrm{HJH}$ and CYP conceived of the study, participated in its design and coordination, and drafted the manuscript. All authors read and approved the final manuscript.

\section{Competing interests}

The authors declare that they have no competing interests.

Received: 14 July 2010 Accepted: 20 April 2011 Published: 20 April 2011

\section{References}

1. Hayat MJ, Howlader N, Reichman ME, Edwards BK: Cancer statistics, trends, and multiple primary cancer analyses from the Surveillance, Epidemiology, and End Results (SEER) Program. Oncologist 2007, 12(1):20-37.

2. Xiao H, Verdier-Pinard P, Fernandez-Fuentes N, Burd B, Angeletti R, Fiser A, Horwitz SB, Orr GA: Insights into the mechanism of microtubule stabilization by Taxol. Proc Natl Acad Sci USA 2006, 103(27):10166-10173.

3. Schiff PB, Fant J, Horwitz SB: Promotion of microtubule assembly in vitro by taxol. Nature 1979, 277(5698):665-667.

4. Cheng YL, Lee SC, Lin SZ, Chang WL, Chen YL, Tsai NM, Liu YC, Tzao C, Yu DS, Harn HJ: Anti-proliferative activity of Bupleurum scrozonerifolium in A549 human lung cancer cells in vitro and in vivo. Cancer Lett 2005, 222(2):183-193.

5. Cheng YL, Chang WL, Lee SC, Liu YG, Lin HC, Chen CJ, Yen CY, Yu DS, Lin SZ, Harn HJ: Acetone extract of Bupleurum scorzonerifolium inhibits proliferation of A549 human lung cancer cells via inducing apoptosis and suppressing telomerase activity. Life Sci 2003, 73(18):2383-2394.

6. Chen YL, Lin SZ, Chang WL, Cheng YL, Harn HJ: Requirement for ERK activation in acetone extract identified from Bupleurum scorzonerifolium induced A549 tumor cell apoptosis and keratin 8 phosphorylation. Life Sci 2005, 76(21):2409-2420.

7. Chen YL, Lin SZ, Chang JY, Cheng YL, Tsai NM, Chen SP, Chang WL, Harn HJ: In vitro and in vivo studies of a novel potential anticancer agent of isochaihulactone on human lung cancer A549 cells. Biochem Pharmacol 2006, 72(3):308-319.

8. Tomioka K, Ishiguro T, litaka Y, Koga K: Stereoselective reactions. XII. Synthesis of antitumor-active steganacin analogs, picrosteganol and epipicrosteganol, by selective isomerization. Chem Pharm Bull (Tokyo) 1986, 34(4):1501-1504

9. Chen $Y L$, Lin PC, Chen SP, Lin CC, Tsai NM, Cheng YL, Chang WL, Lin SZ, Harn HJ: Activation of nonsteroidal anti-inflammatory drug-activated gene-1 via extracellular signal-regulated kinase 1/2 mitogen-activated protein kinase revealed a isochaihulactone-triggered apoptotic pathway in human lung cancer A549 cells. J Pharmacol Exp Ther 2007, 323(2):746-756.

10. Krajewski S, Tanaka S, Takayama S, Schibler MJ, Fenton W, Reed JC: Investigation of the subcellular distribution of the bcl-2 oncoprotein: residence in the nuclear envelope, endoplasmic reticulum, and outer mitochondrial membranes. Cancer Res 1993, 53(19):4701-4714.

11. Bulavin DV, Higashimoto Y, Demidenko ZN, Meek S, Graves P, Phillips C, Zhao H, Moody SA, Appella E, Piwnica-Worms H, Fornace AJ Jr: Dual phosphorylation controls $\mathrm{Cdc} 25$ phosphatases and mitotic entry. Nat Cell Biol 2003, 5(6):545-551.

12. Lammer C, Wagerer $S$, Saffrich R, Mertens D, Ansorge W, Hoffmann I: The cdc25B phosphatase is essential for the G2/M phase transition in human cells. J Cell Sci 1998, 111(Pt 16):2445-2453.

13. Gould KL, Nurse P: Tyrosine phosphorylation of the fission yeast cdc2+ protein kinase regulates entry into mitosis. Nature 1989, 342(6245):39-45

14. Singh RP, Agrawal P, Yim D, Agarwal C, Agarwal R: Acacetin inhibits cell growth and cell cycle progression, and induces apoptosis in human prostate cancer cells: structure-activity relationship with linarin and linarin acetate. Carcinogenesis 2005, 26(4):845-854.

15. Zhang $Y X$, Kong $C Z$, Wang $L H$, Li JY, Liu $X K, X u B, X u C L$, Sun $Y H$ : Ursolic acid overcomes $\mathrm{BCl}$-2-mediated resistance to apoptosis in prostate cancer cells involving activation of JNK-induced BCl-2 phosphorylation and degradation. J Cell Biochem 109(4):764-773.

16. Du L, Lyle CS, Chambers TC: Characterization of vinblastine-induced BCl$\mathrm{xL}$ and $\mathrm{BCl}-2$ phosphorylation: evidence for a novel protein kinase and a coordinated phosphorylation/dephosphorylation cycle associated with apoptosis induction. Oncogene 2005, 24(1):107-117.

17. Susin SA, Lorenzo HK, Zamzami N, Marzo I, Brenner C, Larochette N, Prevost MC, Alzari PM, Kroemer G: Mitochondrial release of caspase-2 and -9 during the apoptotic process. J Exp Med 1999, 189(2):381-394.

18. Slee EA, Harte MT, Kluck RM, Wolf BB, Casiano CA, Newmeyer DD, Wang HG, Reed JC, Nicholson DW, Alnemri ES, Green DR, Martin SJ: 
Ordering the cytochrome c-initiated caspase cascade: hierarchical activation of caspases-2, $-3,-6,-7,-8$, and -10 in a caspase-9-dependent manner. J Cell Biol 1999, 144(2):281-292.

19. Liao CH, Pan SL, Guh JH, Chang YL, Pai HC, Lin CH, Teng CM: Antitumor mechanism of evodiamine, a constituent from Chinese herb Evodiae fructus, in human multiple-drug resistant breast cancer NCI/ADR-RES cells in vitro and in vivo. Carcinogenesis 2005, 26(5):968-975.

20. Yamaguchi K, Lee SH, Eling TE, Baek SJ: A novel peroxisome proliferatoractivated receptor gamma ligand, MCC- 555 , induces apoptosis via posttranscriptional regulation of NAG-1 in colorectal cancer cells. Mol Cancer Ther 2006, 5(5):1352-1361.

21. Baek SJ, Kim JS, Moore SM, Lee SH, Martinez J, Eling TE: Cyclooxygenase inhibitors induce the expression of the tumor suppressor gene EGR-1, which results in the up-regulation of NAG-1, an antitumorigenic protein. Mol Pharmacol 2005, 67(2):356-364.

22. Newman D, Sakaue M, Koo JS, Kim KS, Baek SJ, Eling T, Jetten AM: Differential regulation of nonsteroidal anti-inflammatory drug-activated gene in normal human tracheobronchial epithelial and lung carcinoma cells by retinoids. Mol Pharmacol 2003, 63(3):557-564.

23. Lee SH, Kim JS, Yamaguchi K, Eling TE, Baek SJ: Indole-3-carbinol and 3,3'diindolylmethane induce expression of NAG-1 in a p53-independent manner. Biochem Biophys Res Commun 2005, 328(1):63-69.

24. Eling TE, Baek SJ, Shim M, Lee CH: NSAID activated gene (NAG-1), a modulator of tumorigenesis. J Biochem Mol Biol 2006, 39(6):649-655.

25. Paralkar VM, Vail AL, Grasser WA, Brown TA, Xu H, Vukicevic S, Ke HZ, Qi H, Owen TA, Thompson DD: Cloning and characterization of a novel member of the transforming growth factor-beta/bone morphogenetic protein family. J Biol Chem 1998, 273(22):13760-13767.

26. Shim M, Eling TE: Protein kinase C-dependent regulation of NAG-1/ placental bone morphogenic protein/MIC-1 expression in LNCaP prostate carcinoma cells. J Biol Chem 2005, 280(19):18636-18642.

27. Welsh JB, Sapinoso LM, Kern SG, Brown DA, Liu T, Bauskin AR, Ward RL, Hawkins NJ, Quinn DI, Russell PJ, Sutherland RL, Breit SN, Moskaluk CA, Frierson HF, Hampton GM: Large-scale delineation of secreted protein biomarkers overexpressed in cancer tissue and serum. Proc Natl Acad Sci USA 2003, 100(6):3410-3415.

28. Karan D, Chen SJ, Johansson SL, Singh AP, Paralkar VM, Lin MF, Batra SK: Dysregulated expression of MIC-1/PDF in human prostate tumor cells. Biochem Biophys Res Commun 2003, 305(3):598-604.

29. Wang D, Dubois RN: Prostaglandins and cancer. Gut 2006, 55(1):115-122.

30. Iguchi G, Chrysovergis K, Lee SH, Baek SJ, Langenbach R, Eling TE: A reciprocal relationship exists between non-steroidal anti-inflammatory drug-activated gene-1 (NAG-1) and cyclooxygenase-2. Cancer Lett 2009, 282(2):152-158.

31. Baek SJ, Kim KS, Nixon JB, Wilson LC, Eling TE: Cyclooxygenase inhibitors regulate the expression of a TGF-beta superfamily member that has proapoptotic and antitumorigenic activities. Mol Pharmacol 2001, 59(4):901-908.

32. Macleod KF: The RB tumor suppressor: a gatekeeper to hormone independence in prostate cancer? J Clin Invest 120, 12:4179-4182.

\section{Pre-publication history}

The pre-publication history for this paper can be accessed here: http://www.biomedcentral.com/1471-2407/11/146/prepub

doi:10.1186/1471-2407-11-146

Cite this article as: Chiu et al: Activation of NAG-1 via JNK signaling revealed an isochaihulactone-triggered cell death in human LNCaP prostate cancer cells. BMC Cancer 2011 11:146.

\section{Submit your next manuscript to BioMed Central and take full advantage of:}

- Convenient online submission

- Thorough peer review

- No space constraints or color figure charges

- Immediate publication on acceptance

- Inclusion in PubMed, CAS, Scopus and Google Scholar

- Research which is freely available for redistribution

Submit your manuscript at www.biomedcentral.com/submit
Biomed Central 